\title{
RUSSIAN BANKING SECTOR FOR THREE QUARTERS OF $2016^{1}$ M.Khromov
}

The banking sector profit has grown significantly. At the same time, problems with the rate of return in the banking sector have not evaporated. State owned banks account for nearly all profit. Private banks are balancing on the verge of zero rate of return. Concentration of assets in the banking system remains.

During three quarters of 2016, the Russian banking industry has generated $\mathrm{Rb} 635 \mathrm{bn}$ of accounting profit. This is five time more than a year earlier (for the same period of 2015 , the banking system generated solely $\mathrm{Rb} 127 \mathrm{bn}$ of profit) and three times more than the profit generated for the entire 2015, which constituted Rb 192 bn.

Return on assets (ROA) in annual terms has been gradually recovering. Over nine months of 2016, its level has hit $1.0 \%$ in annual terms, which is not only higher the 2015 level $(0.2 \%)$, when the banks profit was minimal but even higher than the 2014 index (0.9\%). Furthermore, despite a significant growth of profit in the banking industry, its volume still remains rather modest in comparison with the pre-crisis level. In 2011-2012, return on assets surpassed $2 \%$ in annual terms.

Quarterly dynamic of profit is also positive. If in Q1 2016, its volume constituted Rb 109bn, then in Q2 2016, it hit Rb 251bn, and in Q3 - Rb 275bn.

In 2016, return on assets went up from $0.5 \%$ in Q1 to $1.4 \%$ in Q3. In other words, even during the most profitable quarter of 2016 profitability of the banking industry remained below the pre-crisis level.

The fact is that the growth of profit has resulted from slowdown of provision of reserves for potential losses, the so-called "crisis" component. For

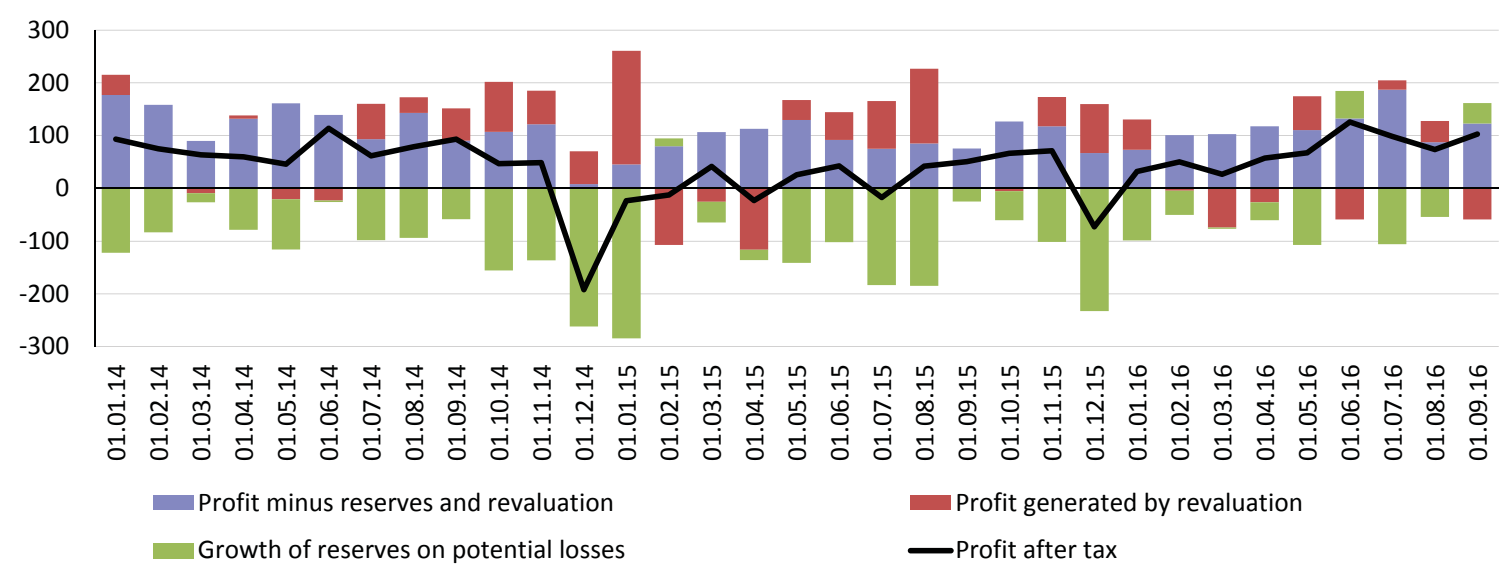

Sources: Bank of Russia, IEP's estimates.

Fig. 1. Main components of banking profit, $R b \mathrm{bn}$

1 This paper was originally published in Online Monitoring of Russia's Economic Outlook No.17(35). 
example, for three quarters of 2016, growth of bank reserves for potential losses and other assets came to $\mathrm{Rb} 358 \mathrm{bn}$, which is significantly less than was registered for the corresponding periods of 2014 (Rb 649 bn) and 2015 ( $\mathrm{Rb} 63 \mathrm{bn}$ ). Thus, easing of loan loss provisioning, in other words when the risk level in bank assets has slowed down, has become the main factor for profitability growth in the banking industry in 2016.

Simultaneously, net profit of banks generated by revaluation of accounts denominated in foreign currency has gone down. During Q1-Q3 2016, it was negative ( $\mathrm{Rb}-42 \mathrm{bn})$, meanwhile a year earlier for the same period banks earned $\mathrm{Rb} 288 \mathrm{bn}$ on ruble's depreciation. This is due to the dynamic change of the cost of national currency. Owing to the fact that banks maintain positive currency position, currency assets surpass currency liabilities, ruble's strengthening results in losses and ruble's depreciation leads to additional earnings. During three quarters of 2016, ruble strengthened to US dollar by $13.3 \%$, and to euro - by $10.9 \%$. A year earlier in $\mathrm{H} 12015$, ruble exchange rate to US dollar, on the contrary fell by $16.9 \%$, and to euro - by $7.9 \%$.

At the same time, net operating income, in other words revenue minus increment of loan loss provisioning and net income generated by revaluation of accounts denominated in foreign currency, has also gone up. During three quarters of 2016, net operating income constituted $\mathrm{Rb} 1,035 \mathrm{bn}$, which is by $29 \%$ more than for the same period of 2015 (Rb 802 bn). Return on assets according to this component somewhat moved up during the year constituting $1.7 \%$ in annual terms in comparison with $1.4 \%$ in $\mathrm{H} 12015$. As a comparison, up to 2014, in $\mathrm{H} 1$ the banks managed to generate net operating income to the tune of $2.7-2.9 \%$ of the volume of medium term assets on year-onyear. This means that currently profitability of net operating income is nearly half its normal level characteristic for the periods of sustainable development of the banking industry.

Sberbank still accounts for a major share of banking profit. During three quarters of 2016, Sberbank's profit hit Rb $555 \mathrm{bn}-76 \%$ of the profit of entire banking sector, in other words Sberbank, which accounts for less than $30 \%$ of total assets in the banking sector, has generated 5-time more profit than all other banks taken together. However, this is a step forward in normalization of income in the banking industry because at end-2015 profit of Sberbank ( $\mathrm{Rb} 282 \mathrm{bn}$ ) surpassed profit of the entire banking sector (Rb 192bn) - all other banks as a whole registered losses.

Sberbank together with banks affiliated to the RF government and the largest state company Gazprom ${ }^{1}$, account for nearly Rb 555bn of profit of $\mathrm{Rb} 635 \mathrm{bn}$ generated by the entire banking industry.

This demonstrates that other private banks teeter on the brink of zero profitability. Private segment of the banking sector remains highly unattractive from the investment point of view for the owners of banks. Assistance provided to banks by the private capital is limited to mainly maintaining resiliency of the existing business without significant investment in rapid development. This fact most likely will result in further strengthening of positions of state banks on the market of banking services and continued growth of assets concentration in the banking industry.

1 VTB Group banks (VTB, VTB24 and Bank of Moscow), Rossekhozbank and GPB. 